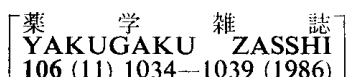

活性酸素による生体障害に関する研究（第 1 報）アロキサン糖尿病発症 に対する種々ハイドロキシル・ラジカル消去剤の防御作用

\author{
桜井光一, $*$ 三浦俊明，小橧健人 \\ 北海道薬科大学
}

\title{
Studies on Biological Damage by Active Oxygen. I. Protective Effect of Various Hydroxyl Radical Scavengers against Alloxan-Induced Diabetes
}

\author{
Koichi Sakurai,* Toshiaki Miura and Taketo Ogiso \\ Hakkaido Institute of Pharmaceutical Sciences, \\ 7-1 Katsuraoka-cho, Otaru, 047-02, Japan
}

(Received May 19, 1986)

\begin{abstract}
Protective effects of several hydroxyl radical (HO-) scavengers and superoxide dismutase on alloxan-induced diabetes were studied in vivo. Thiourea, methylthiourea, dimethylthiourea and ethanol, HO - scavengers (type 1), which easily cross cellular membranes, protected initial- and permanent-hyperglycemia. In contrast, mannitol and sorbitol (type 2), which can not cross cellular membranes, protected initial-hyperglycemia, but did not protect permanent-hyperglycemia. Furthermore, superoxide dismutase which is not expected to be incorporated into pancreatic $\beta$-cell, strongly protected initial-hyperglycemia but partially protected permanent-hyperglycemia.

These results suggest that $\mathrm{HO}$. primarily damages the $\beta$-cell membranes by acting at or neat a site involved in insulin release, and subsequently damages the intracellular components. From these results, the possible protective mechanism of these scavengers was discussed.
\end{abstract}

Keywords - alloxan-induced diabetes; hydroxyl radical scavenger; thiourea; mannitol; superoxide dismutase; insulin

アロキサンは膵臟 $\beta$ 細胞に障害を与光糖尿病を誘発する，一方，種々のハイドロオキシル・ラジカル (HO·) の消去剂をあらかじぬ動物に投与して拉くとアロキサン誘導の糖尿病が阻止されることから，アロキサンは生体 内でジアルル酸に還元され，再び酸化される過程で HO ・ が発生し，それによって膵臟 $\beta$ 細胞が障害されて，糖 尿病が誘発されると考觉られている. ${ }^{1-4)} こ の こ と は$ in vitro に打いて子還元剤としてアスコルビン酸を用いた系 によって示されている.5

アロキサン糖尿病においては最初に膵臟 $\beta$ 細胞の膜が障害され，引き続いて細胞内の障害が誘発されることが

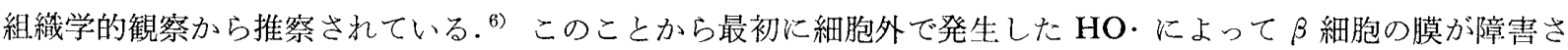
れ，その後細胞内に取り达ま机たアロキサンに上り発生した HO・が細胞内障害を誘発すると考兄られる。一方， HO．消去剂は生体膜に対する基本的な性質から 2 種類に分類することができる１つは細胞膜を容易に通過し て細胞内にとり込末机るもの (type 1)，もら1つは細胞膜を通過できず，細胞外にとどまるすの (type 2) である. Type 1 飞は脂肪鎖アルコール類, ジィチルスルホキ+イド, 尿素誘導体, type 2 にはマニトール，ソルビトール

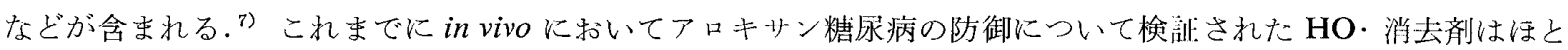
んどが容易に細胞内にとり这まれる type 1 のものであり, ${ }^{1-4)}$ 膜を通過できない type 2 の消去剤の防御作用に ついては検㯎されていない。

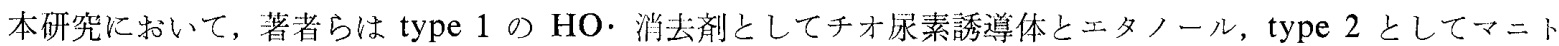
一ルとソルビトールを用いてこれらの消去剂のアロキサン誘導の糖尿病に対する防御作用の相違についてinvivo で検討し，符「の知見を得たので解告する。 


\section{実 験 $\quad$ 部}

試薬『アロキサン, チオ尿素 (TU), マニトール,ソルビトール, Glucose B Test Wako はいずれも和光純 薬工業社より,メチルチオ尿素 (MTU), ジメチルチオ尿素 (DMTU) はアルドリッチ社より得た。キサンチン・ オキシダーゼ(バターミルク由来) はベーリンガー・マンハイム社より購入した. チオバルビッール酸はメルク・ ジャパン社より購入し， 3 回再結晶して类䥒に用いた。インスリン・リアビーズはダイナボット社より得た。そ の他の試薬は市敗特級品を用いた。

動物体重約 $20 \mathrm{~g}$ の ddY 雄マウスを 24 時間絶食したのち，アロキサンを窒素置換した生理食塩水に溶解 し，、ウス尾静脈より投与した。対照群には生理食塩水を投与し，両群とも投与後ただちに飼料(オリエンタル酵 母社 MF)にて飼育したアロキサン投与後の各一定時間に尾静脈より採血し，1200 rpm，10 分間遗心して血漿を 分離した。

血糖值及びインスリンの定量＼cjkstart血中グルュースは酵素法により測定し， ${ }^{8)}$ インスリンは二抗体法で測定し た. ${ }^{\text {r) }}$

HO.の消去活性の測定 HO・は Gutteridge らの方法 ${ }^{10)}$ に從い，EDTA-Fe ${ }^{3+}$ 存在下キサンチン・オキ シダーゼ系で発生させ，消去剤によるデオキシリボースの分解阻止率を求めた。キサンチン・オキシダーゼ系は

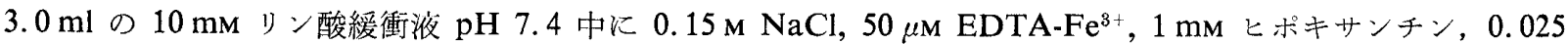
unit のキサンチン・オキシダーゼを含み，この反応系に $1 \mathrm{mM}$ デオキシリボースを加え， $37^{\circ} \mathrm{C} て ゙ 5$ 分間インキ ュベートした．系中に $0.3 \mathrm{ml}$ のトリクロル酢酸を加えて反応を停止させたのり $0.75 \mathrm{ml} の 1 \%$ チオバルビッー 儿酸を加光, 15 分間, $100^{\circ} \mathrm{C}$ で加熱した。 その後, 反応液を流水中で冷却し， $532 \mathrm{~nm}$ の吸光度を分光光度計 (Hitachi Model 200-20) で測定した.

\section{結 果}

\section{TU 及びマニトールによるアロキサン誘導高血糖の抑制}

Type 1 の消去剤として TU, type 2 の消去剂としてマニトールを用いてアロキサン誘導の高血糖に対する影 響について検討した．Fig. 1 に示すようにマウスにアロキサンを投与すると 1 時間後には血糖值は著しく増加 し, 約 $500 \mathrm{mg} / 100 \mathrm{ml}$ となった (初期高血糖).その後わずかに血糖值は減少したが，6時間以後血糖値は再び増 加して 24 時間後には約 $580 \mathrm{mg} / 100 \mathrm{ml}$ となった。以後血糖值はほとえど変化せず，動物は持続的高血糖を示し た.

アロキサン投与 30 分前に TUを投与しておくと 1 時間後の初期高血糖の発現を有意に抑制したばかりでなく その後 24 時間に至るまでに血糖值は低下し続け持続的高血糖の発現も強く抑制した。一方，マニトールを投与 しておくとアロキサン投与 1 時間後に認められる血糖值の上昇（初期高血糖）は有意に抑制された。しかしなが ら，その後血糖值は徐々に上昇し，アロキサン投与 24 時間後には約 $490 \mathrm{mg} / 100 \mathrm{ml}$ となりマニトールは持続的

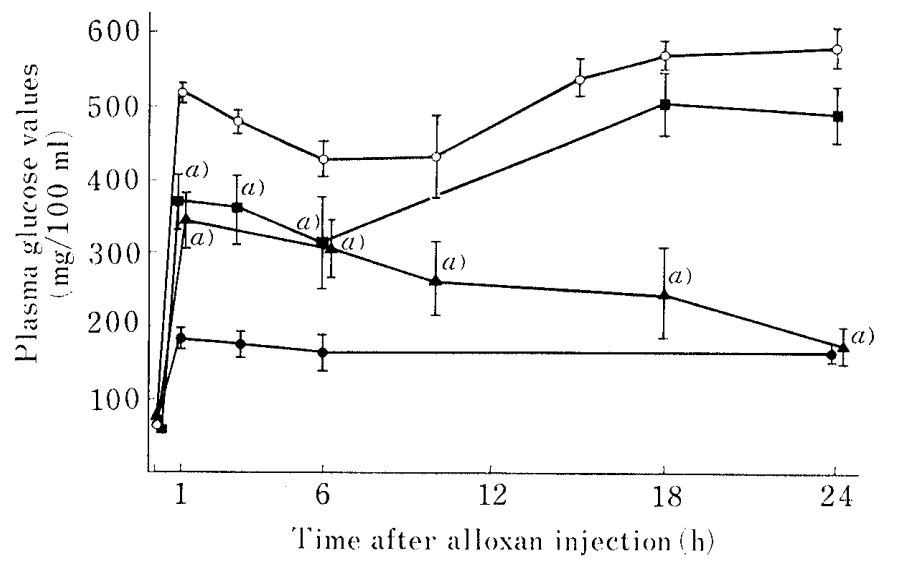

Fig. 1. Effect of Mannitol and Thiourea on Alloxan-Induced Hyperglycemia

Mice were injected alloxan $(50 \mathrm{mg} / \mathrm{kg} \mathrm{b.w.;} \bigcirc)$ or physiological saline (O). Mannitol $(2.0 \mathrm{~g} / \mathrm{kg} \mathrm{b.w.;D)} \mathrm{and}$ thiourea $(1.0 \mathrm{~g} / \mathrm{kg} \mathrm{b.w.;} \Delta)$ were injected i.p. to the mice $30 \mathrm{~min}$ prior to alloxan injection. Each point is the mean \pm S.E. of $6-34$ mice. a) $p<0.05$, compared to alloxan-injected mice. 
高血糖を有意に抑制しなかった。なお生理食塩水の単独投与により，血糖值は約倍に増加したがこれは紿食状態 から飼料を提取することによる血糖值の上昇と考えられる。また TU，マニトールの単独投与では血糖值の変動 は全く認められなかった。

以上の結果より，TU は初期高血糖のみならず持続的高血糖をも強く抑制するのに対し，マニトールは初期高 血糖のみを抑制し，持続的高血糖はほとんど抑制せず，HO・消去剤の間に明らかな作用の相違があることが分か った.

\section{TU 及びマニトールによるアロキサン誘導血中インスリン低下に対する防御}

血糖值の変動が膵藏 $\beta$ 細胞の障書を反映したものであることを確認するために血中インスリン䟴度の変動に ついて検討した，Table I に羊すようにアロキサン投与 1 時間後において血中インスリン裖度は著しく低下し約 $14 \mu \mathrm{U} / \mathrm{ml}$ の值を示した. アロキサン投与 6 時間後に血中インスリン濃度は一過性の上䔣を示したが，24侍間後 には再び低下して約 $15 \mu \mathrm{U} / \mathrm{ml}$ の值を示した。

これに対し，TUはアロキサン投与 1 及び 24 時間後の血中インスリン濃度の低下を有意に抑制した。一方，一 ニトールはアロキサン投与 1 時間後の血中インスリン濃度の低下を有意に抑制したが，アロキサン投与. 24 時間 後の血中インスリン濃度の低下を有意には抑制しなかった。データーには示さないが，マニトール，及び TUの 単独投与は血中インスリン濃度に影響を与えることはなかった。

これらの結果よりアアロキサンによる初期又は持続的な血糖值の上昇がアロキサンの膵臓 $\beta$ 細胞の障害による インスリン分泌低下に起因すること，李たTUはアロキサン投与後初期及び持続的に起こるインスリン分泌の低 下をともに抑制するが，マニトールは初期に起こるインスりン分泌の低下のみを抑制することが分かった。

TABLE I. Effect of Mannitol and Thiourea on Plasma Insulin Values in Alloxan Injected Mice

\begin{tabular}{lccccc}
\hline \multirow{2}{*}{ Group } & \multicolumn{5}{c}{ Time after alloxan injection $(\mathrm{h})$} \\
\cline { 2 - 7 } & 0 & 1 & 6 & 24 \\
\hline Saline & \multicolumn{7}{c}{ Plasma insulin $(\mu \mathrm{U} / \mathrm{ml})$} \\
Alloxan & $20.0 \pm 0.7(3)$ & $32.5 \pm 1.6^{a)}(3)$ & $33.0 \pm 0.9$ & $(3)$ & $40.0 \pm 1.3^{a)}(3)$ \\
Thiourea +alloxan & $16.0 \pm 1.4(3)$ & $25.3 \pm 0.7^{a)}(3)$ & $27.1 \pm 1.6^{a)}(3)$ & $33.3 \pm 3.6^{a)}(3)$ \\
Mannitol +alloxan & $17.6 \pm 0.8(3)$ & $21.7 \pm 0.7^{a)}(3)$ & $\left.24.1 \pm 0.9^{a}\right)(3)$ & $18.0 \pm 1.8$ & $(3)$ \\
\hline
\end{tabular}

Experimental conditions were same as described in Fig. 1. Values represent the mean \pm S.E. Number in parentheses represents number of animals. a) $p<0.05$ compared to alloxan injected mice.

\section{その他の HO・消去剤によるアロキサン誘導の高血糖発症の防御}

TU やマニトールを含も他の HO・消去剤のアロキサン誘導高血糖に対する影響について検討した．Table II に示すように type 1 に属する消去剂, TU, MTU, DMTU, エタノールはいずれも投与量に依存してアロキサン による初期高血糖及び持続的高血糖の発症を防御した。一方, type 2 に属する消去剤マニトール，ソルビトール は投与.量に依存して初期高血糖の発症を防御したが，持続的高血糖の発症を防御しなかった。李た，この垁験に 用いた消去剤を動物に単独投与しても血糖值の变動は認められなかった。これらの結果は前述した結果と一致し て type 1, type 2 に分類される HO・消去剤の間でアロキサン誘導の高血糖発症に対する防御作用に明らかな相 違があることを示すものであった，以上のことより，type 1 の HO・消去戍はHO・による ど完全に防御するのに対して, type 2 の消去郕は初期に誘発されるインスリン分泌の低下のみを防御するものと 推定した.

\section{HO· 消去剤の HO 消去活性}

Type 1 及び type 2 の HO 消去剤の in vivo でのアロキサン誘導高血糖の防御效果と HO・消去活性の関係 について検討した。 Table III に示すように type 1 の消去剂 TU, MTU, DMTU は, 10 mM 濃度に括いて,

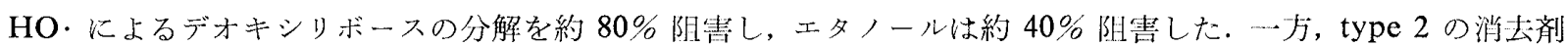
マニトール，ソルビトール $(10 \mathrm{~mm})$ は HO・Kよるブオキシリボースの分解を約 $70 \%$ 阻止した。これらの結果 
TABLE II. Effect of Various Hydroxyl Radical Scavengers on Alloxan-Induced Hyperglycemia

\begin{tabular}{|c|c|c|c|}
\hline \multirow{2}{*}{ Scavengers } & \multirow{2}{*}{$\begin{array}{c}\text { Dose } \\
\text { (g/kg b.w.) }\end{array}$} & \multicolumn{2}{|c|}{ Time after alloxan injection (h) } \\
\hline & & 1 & 24 \\
\hline & & \multicolumn{2}{|c|}{ Plasma glucose values $(\mathrm{mg} / 100 \mathrm{ml})$} \\
\hline Saline & - & $526.9 \pm 13.4$ & $579.9 \pm 25.1$ \\
\hline \multirow[t]{2}{*}{ Thiourea } & 0.5 & $362.9 \pm 60.8^{a)}(3)$ & $345.3 \pm 77.0^{a)}(3)$ \\
\hline & 1.0 & $345.2 \pm 37.4^{a)}(7)$ & $172.6 \pm 27.0^{a)}(6)$ \\
\hline \multirow[t]{2}{*}{ Methylthiourea } & 0.5 & $267.9 \pm 65.8^{a)}(3)$ & $170.8 \pm 28.1^{a)}(3)$ \\
\hline & 1.0 & $131.5 \pm 22.6^{a)}(3)$ & $265.8 \pm 110.3^{a)}(3)$ \\
\hline \multirow[t]{2}{*}{ Dimethylthiourea } & 0.5 & $175.9 \pm 17.6^{a)}(3)$ & $299.6 \pm 58.6^{a}(3)$ \\
\hline & 1.0 & $139.9 \pm 11.2^{a)}(4)$ & $163.8 \pm 11.7^{a)}(5)$ \\
\hline \multirow[t]{2}{*}{ Ethanol } & 2.0 & $446.2 \pm 16.5^{a)}(6)$ & $511.6 \pm 39.0$ \\
\hline & 4.0 & $311.5 \pm 34.3^{a)}(8)$ & $396.3 \pm 28.4^{a)}(3)$ \\
\hline \multirow[t]{3}{*}{ Mannitol } & 0.5 & $510.1 \pm 25.5 \quad(8)$ & $484.6 \pm 49.2 \quad(3)$ \\
\hline & 1.0 & $388.8 \pm 26.1^{a)}(17)$ & $501.4 \pm 73.9 \quad(3)$ \\
\hline & 2.0 & $353.0 \pm 28.8^{a)}(14)$ & $488.5 \pm 37.1 \quad(6)$ \\
\hline \multirow[t]{2}{*}{ Sorbitol } & 1.0 & $413.2 \pm 52.4^{a)}(8)$ & $517.2 \pm 37.3 \quad(3)$ \\
\hline & 2.0 & $415.0 \pm 31.6^{a)}(9)$ & $511.8 \pm 37.7 \quad(6)$ \\
\hline
\end{tabular}

Mice were injected i.p. with hydroxyl radical scavengers or saline 30 min prior to alloxan. Other conditions were same as described in Fig. 1. Values represent the mean \pm S.E. Number in parentheses represents number of animals. $a$ ) $p<0.05$ compared to saline.

TABLE III. Inhibition of Deoxyribose Degradation by Various Hydroxyl Radical Scavengers

\begin{tabular}{lccc}
\hline Scavengers & $\begin{array}{c}\text { Concentration } \\
(\mathrm{mm})\end{array}$ & O.D. 532 nm & $\begin{array}{c}\text { \% inhibition } \\
\text { of degradation }\end{array}$ \\
\hline Control & - & 0.465 & - \\
Thiourea & 10.0 & 0.073 & 84.3 \\
Metylthiourea & 10.0 & 0.077 & 83.5 \\
Dimethylthiourea & 10.0 & 0.107 & 77.0 \\
Ethanol & 10.0 & 0.275 & 41.0 \\
Mannitol & 10.0 & 0.162 & 65.2 \\
Sorbitol & 10.0 & 0.156 & 66.5 \\
\hline
\end{tabular}

Various scavengers were added to the xanthine oxidase system containing $1 \mathrm{~mm}$ deoxyribose. Other conditions were described in Experimental.

より実験に用いた type 1 及び type 2 の HO・消去剤はいずれも高いHO・消去活性を有していることが明らか となった。

このことより，本実験に用いた HO・消去剤の間に認められるアロキサン誘導の高血糖に対する防御効果の違 いは HO・消去剂の HO・消去活性の違いによるものではなく細胞膜に対する性質の違いによるものであると推 定した.

\section{Superoxide Dismutase によるアロキサン誘導高血糖発現の防御}

Superoxide dismutase (SOD) は $\mathrm{O}_{2}^{-}$を消去し, Haber-Weiss 反応を介した機構での HO・の発生を阻此する ことができる.一方, SOD は高分子であるため動物に投与しても細胞膜を通過せず, type 2 の HO消去剤と同 様に初期高血糖の発現を防御し得るが持続的高血糖の発現は防御されないものと子想される.

Table IV に示すようにアロキサン投与の直前に SOD を投与すると投与量に依存して初期高血糖は強く抑制 された。しかしながら持続的高血糖はSOD の低投与量 $(250 \mathrm{mg} / \mathrm{kg})$ では抑制されず，高投与量 $(500 \mathrm{mg} / \mathrm{kg})$ の ときのみわずかに抑制された。熱変性によって失活したSODを投与してもアロキサン誘導のいずれの高血糖の 発現にも全く影響しなかった。また SODを正常動物に投与しても血糖値には有意な変動は認められなかった。 
TABLE IV. Effect of SOD on Alloxan-Induced Hyperglycemia

\begin{tabular}{lcccc}
\hline \hline \multirow{1}{*}{ Group } & $\begin{array}{c}\text { Dose } \\
\text { (mg/kg b.w. })\end{array}$ & \multicolumn{2}{c}{ Time after alloxan injection $(\mathrm{h})$} \\
\cline { 3 - 5 } & & \multicolumn{3}{c}{ Plasma glucose values $(\mathrm{mg} / 100 \mathrm{ml})$} \\
Saline & - & $526.7 \pm 13.4(34)$ & $579.9 \pm 25.1$ & $(10)$ \\
SOD & 250 & $380.5 \pm 31.6^{b)}(4)$ & $519.0 \pm 41.4(4)$ & $(4)$ \\
SOD & 500 & $312.0 \pm 50.4^{b)}(3)$ & $450.1 \pm 42.7^{a)}(3)$ \\
Inactivated SOD & 500 & $568.5 \pm 20.7(4)$ & $586.1 \pm 40.2(4)$ & $(4)$ \\
\hline
\end{tabular}

Mice were injected i.v. with SOD or saline $5 \mathrm{~s}$ prior to alloxan injection. Other conditions were same as described in Fig. 1. Number in parentheses represents number of animals. a) $p<0.05 ; b) p<0.01$, compared to saline injected mice.

以上の結果より，SOD の作用は type 2 の HO消去剂に類似しているものと考えた。なぜなら type 1 の HO・消去剂は初期高血糖に比べて持続的高血糖をほぼ同じ程度か又はより強く抑制するのに対して type 2 の HO・消去剂は初期高血糖のみを強く抑制するからである.

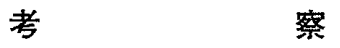

多くの研究者の報告と同様に, ${ }^{11-13)}$ 動物にアロキサンを投与すると初期及び持続的高血糖が観祭され，これに 伴い血中インスリン濃度は低下した (Fig. 1, Table I). またアロキサン投与 1 時間以内に著しい血糖值の上䒜が 観察されたこととアロキサンが投与後数分以内に血中より消失し， ${ }^{14)}$ すみやかに細胞に取り込まれる ${ }^{15)}$ 報告とを 考えあわせると，アロキサンが投与後直ちに $\beta$ 細胞に障害をあたえる可能性を示唆している.

今回の実験において, type 1 の HO·消去剤, TU, MTU, DMTU, エタノールはいずれも初期及び持続的高 血糖の発現を防御し, type 2 の HO・消去剤マニトール及びンルビトールは初期高血糖の発現のみを防御した (Table II). また実験に用いた HO・消去剤はいずれも強いHO・消去活性を示した (Table III).このことは， type 1 type 2 の HO 消去剂によるアロキサン誘導高血糖の発症に対する防御作用の相違は HO・消去剂 の HO・消去活性によるものではなくHO・消去剤の細胞膜に対する性質の相違によるものと考えた。すなわも type 1 の HO ·消去剂は細胞膜を通過して細胞の内と外に分布するのに対して, type 2 の H 消去剤は細胞膜 を通過できないため, 細胞外のみに分布することによるものであると考えられる. Uchigata ら ${ }^{18)}$ は in vivoでフ ロキサンを投与すると脺蔵 $\beta$ 細胞の DNA 鎖が切断されることを示し，これがアロキサンを介して発生した

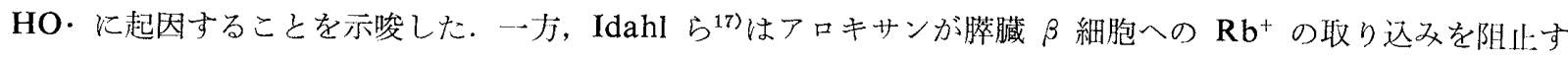
ることからアロキサンにより細胞膜が障害されたものと考えた。また in vitro においては，グルコースによる膵 蔵 $\beta$ 細胞からのインスリンの分泌がアロキサンにより阻彗され，HO・消去剂ジメチル尿素がアロキサンによる

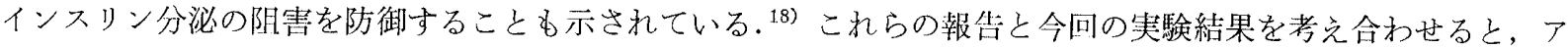
ロキサン投与によってまず $\beta$ 細胞の膜が障害されてインスリン分泌が阻害され，引き続いて細胞内にとり込まれ たアロキサンによって DNA のような細胞内成分が障害され，インスリン合成は阻害され，更に細胞の障害が進 行するものと考党られる.

結論として, type 1 消去剤は膜を通過して細胞内にとり込まれるので脺臓 $\beta$ 細胞の内と外でアロキサンを介 して発生した HO.を消去して細胞の酸化的障害を阴止し，糖㽷病の発生を防ぐと考えた。これに対して，type 2 消去剂は細胞膜を通過できず細胞外にとどまるため細胞外に敃いて発生した HO・を消去し得るが細胞内にとり 込まれたアロキサンによって拻起される障害は防御し得ないと考えた。

一方, SOD 投与によるアロキサン誘導高血糖に対する防御効果は, type 2 の $\mathrm{HO}$. 消去剤の效果と類似した (Table IV).このことはSOD は細胞膜を通過しないため, 細胞外に発生する $\mathrm{O}_{2}{ }^{-}$のみを消去することによって二 次的に産生する HO・の発生を阻止する結果であると考えられる。一方，アロキサンが膜を通過したのち起こす 細胞内での障害はもはや細胞外の SOD では防御できないものと考元た．しかしながら，高投与量 $(500 \mathrm{mg} / \mathrm{kg})$ のSODによってわずかに持続的高血糖が防御された理由について次のように考えた.

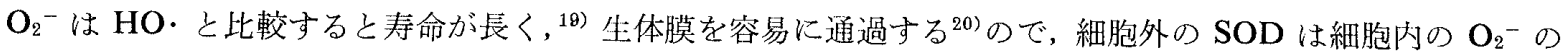


濃度を低下させることが考えられる。事実，細胞内の $\mathrm{O}_{2}^{-}$による障害に対する細胞外 SOD の防御効果が in vitro 赤血球膜 vesicle を用いた系で示されている. ${ }^{20)}$ しかしながら, Grankvist ら ${ }^{21}$ はアロキサン糖尿病の発症 がポリエチレングリコールと結合させた SOD $(200 \mathrm{mg} / \mathrm{kg})$ の投与で有意に防御されることを報告しているので， SOD のアロキサン糖尿病に対する防御効果の詳細については更に検討する必要がある.

\section{引用文献}

1) R. E. Heikkila, H. Barden, G. Cohen, J. Pharmacol. Exp. Ther., 190, 501 (1974).

2) R. E. Heikkila, B. Winstor, G. Cohen, H. Barden, Biochem. Pharmacol., 25, 1085 (1976).

3) R. E. Heikkila, Eur. J. Pharmacol., 44, 191 (1977).

4) R. E. Heikkila, F. S. Cabbat, Eur. J. Pharmacol., 52, 57 (1978).

5) G. Cohen, R. E. Heikkila, J. Biol. Chem., 249, 2447 (1974).

6) S. J. Cooperstein, D. Watkins (eds.), "The Islets of Langerhans," Academic Press, 1981, p. 392.

7) S. Marklund, J. Grankvist, I. B. Taljedal, "Oxy Radicals and Their Scavenger Systems Volume II, Cellular and Medical Aspects," ed. by R. A. Greenwald, G. Cohen, Elsevier Biochemical, New York, 1982, p. 96.

8) W. Werner, H. G. Rey, H. Wielinger, Fresenius. Z. Anal. Chem., 252, 224 (1970).

9) M. Awai, M. Narasaki, Y. Yamanoi, S. Seno, Am. J. Pathol., 95, 663 (1979).

10) J. M. C. Gutteridge, FEBS Lett., 128, 343 (1981).

11) F. D. W. Luhens, Physiol. Rev., 28, 304 (1948).

12) I. Lundquist, C. Rerup, Eur. J. Pharmacol., 2, 35 (1967).

13) H. Nakakimura, K. Mizuno, Chem. Pharm. Bull., 28, 2207 (1980).

14) N. Siliprandi, Experientia, 4, 228 (1948).

15) D. C. Weaver, M. L. McDaniel, P. E. Lacy, Endocrinology, 102, 1847 (1978).

16) Y. Uchigata, H. Yamamoto, A. Kawamura, H. Okamoto, J. Biol. Chem., 257, 6084 (1982).

17) L. A. Idahl, A. Lernmark, J. Sehlin, I. B. Taljedal, Biochem. J., 162, 9 (1977).

18) L. J. Fischer, S. A. Hamburger, Life Sci., 26, 1405 (1980).

19) 浅田浩二, 生化学, 48, 226 (1976).

20) R. E. Lynch, I. Fridovich, J. Biol., Chem., 253, 1838 (1978).

21) K. Grankvist, S. Marklund, I. B. Taljedal, Nature (London), 294, 158 (1981). 